\title{
Protracted Shedding of Oocysts of Neospora caninum by a Naturally Infected Foxhound
}

\author{
Author(s): J. W. McGarry, C. M. Stockton, D. J L. Williams, and A. J. Trees \\ Source: Journal of Parasitology, 89(3):628-630. 2003. \\ Published By: American Society of Parasitologists \\ DOI: http://dx.doi.org/10.1645/0022-3395(2003)089[0628:PSOOON]2.0.CO;2 \\ URL: http://www.bioone.org/doi/full/10.1645/0022-3395\%282003\%29089\%5B0628\%3APSOOON \\ $\% 5 \mathrm{D} 2.0 . \mathrm{CO} \% 3 \mathrm{~B} 2$
}

BioOne (www.bioone.org) is a nonprofit, online aggregation of core research in the biological, ecological, and environmental sciences. BioOne provides a sustainable online platform for over 170 journals and books published by nonprofit societies, associations, museums, institutions, and presses.

Your use of this PDF, the BioOne Web site, and all posted and associated content indicates your acceptance of BioOne's Terms of Use, available at www.bioone.org/page/terms_of_use.

Usage of BioOne content is strictly limited to personal, educational, and non-commercial use. Commercial inquiries or rights and permissions requests should be directed to the individual publisher as copyright holder. 


\title{
Organization of the Musculature of Schistosome Cercariae
}

\begin{abstract}
G. R. Mair, A. G. Maule, B. Fried ${ }^{\star}$, T. A. Daył, and D. W. Halton $\neq$, Parasitology Research Group, School of Biology and Biochemistry, Medical Biology Centre, Queen's University Belfast, Belfast BT9 7BL, U.K. *Department of Biology, Lafayette College, Easton, Pennsylvania 18042. †Department of Biomedical Sciences, lowa State University, Ames, lowa 50011-1250. ‡To whom correspondence should be
\end{abstract} addressed.e-mail:d.halton@qub.ac.uk

ABSTRACT: Phalloidin-fluorescein isothiocyanate staining of filamentous actin was used to identify muscle systems within the cercariae of Schistosoma mansoni. Examination of labeled cercariae by confocal scanning laser microscopy revealed distinct organizational levels of myofiber arrangements within the body wall, anterior cone, acetabulum, and esophagus. The body wall throughout showed a typical latticelike arrangement of outer circular and inner longitudinal myofibers, with an additional innermost layer of diagonal fibers in the anterior portion of the body. Circular and longitudinal fibers were also evident in the anterior organ and esophagus and, to some extent, the ventral acetabulum. Most striking was the striation of the cercarial tail musculature.

Schistosoma mansoni is a digenean flatworm parasite whose freeswimming cercariae are the highly motile invasive stages that penetrate human skin to establish parasitemia. Cercariae depend on a well-developed behavioral modality through thermal and chemical signals, involving coordinated nerve-muscle function to locate the human host, and are equipped with a stage-specific tail for swimming (Fetterer et al., 1978; Cohen et al., 1980; Combes et al., 1994; Haas et al., 1997). Schistosoma mansoni cercariae are $\sim 300 \mu \mathrm{m}$ in length and $70 \mu \mathrm{m}$ in width; anatomically, each is divided into an anterior body and posterior tail, the latter consisting of a stem and terminating in short, paired furcae (Fig. 1A). The body bears an oral sucker or anterior cone, with the mouth opening on its ventroanterior tip, and a ventral acetabulum located in the last quarter of the main body. Both the tail stem and furcae are believed to be cast off upon entry into the host and function mainly as a swimming device during host location.

To identify the distribution and anatomical characteristics of cercarial muscle fiber systems, we used fluorescein isothiocyanate (FITC)-labeled phalloidin staining of filamentous actin (F-actin) in conjunction with confocal scanning laser microscopy (CSLM) (Reiter et al., 1996; Mair et al., 2000). For muscle staining, cercariae $(n=>50)$ were recovered from Biomphalaria glabrata snails and fixed in $4 \%$ paraformaldehyde for $24 \mathrm{hr}$, followed by a 3-hr wash in phosphate-buffered saline (PBS). Staining of F-actin was achieved by incubation of whole larvae in a $20 \mathrm{mg} / \mathrm{ml}$ solution of FITC-labeled phalloidin (Sigma Chemical Co., Poole, U.K.) in PBS overnight at 4 C. Cercariae were finally washed for $2 \mathrm{hr}$ with 3 buffer changes and mounted on subbed slides. The use of whole-mount preparations in conjunction with the optical sectioning (Z-series) facility of CSLM (Leica TCS-NT, Leica Microsystems, Milton Keynes, U.K.) enabled accurate identification of specific muscle fiber arrangements. Cercarial structure was also observed using a scanning electron microscope (Jeol JSM35CF, Jeol (U.K.) Ltd., Welwyn Garden City, U.K., at $15 \mathrm{kV}$ ) after fixation of specimens for 2 $\mathrm{hr}(\mathrm{n}=>25)$ in a $3: 1$ mixture of $4 \%$ glutaraldehyde in $0.1 \mathrm{M}$ cacodylate buffer ( $\mathrm{pH} 7.2$ ) and $0.5 \%$ osmium tetroxide (aq), 3 changes in bufferwash, dehydration through acetone, and sputter-coating with gold.

Staining of cercariae with phalloidin-FITC revealed the characteristics of body wall musculature and, to some degree, the derived structures of the anterior cone and acetabulum. The organization of the muscle fibers within the body wall is similar to that in the adult worm (Mair et al., 2000), consisting of a latticelike arrangement of outer circular and inner longitudinal muscle fibers (Fig. 2A-C) whose contraction presumably enables lengthening and shortening of the body segment, respectively. The longitudinal fibers have an approximate diameter of $5 \mu \mathrm{m}$, and the circular fibers measure approximately $3 \mu \mathrm{m}$ in diameter. Whereas diagonal fibers are abundant in the adult schistosome and are present throughout the entire body (Mair et al., 2000), cercariae contain only 3 bundles of diagonal fibers restricted to the anterior half of the main body (Fig. 2A, C). These bundles cross each other at a characteristic angle of approximately $120^{\circ}$, an arrangement that is also main- tained in adult worms. Diagonal muscle fibers lie below the layer of longitudinal muscle fibers and are arranged in bundles comprising 2 or more muscle fibers. They are present both in a dorsal and ventral position, and their activity presumably allows side-to-side movement of the forebody and a degree of torsion. No attempt has been made to correlate the arrangement of somatic muscle types with specific movements of the cercariae, but for a functional interpretation of flatworm musculature, the works of Hooge and Tyler (1999) and Tyler and Rieger (1999) should be consulted.

The anterior cone surrounds the mouth and, in common with the body wall musculature, contains tightly arranged circular fibers and broader longitudinal muscle fibers (Fig. 2D). The muscle fibers within the anterior cone were not clearly discernible with phalloidin-FITC staining.

A few circular fibers occupy the outer rim of the ventral acetabulum (Fig. 2E). The core of the acetabulum contains a seemingly unstructured array of muscle fibers and is anchored to the body wall by 3 pairs of
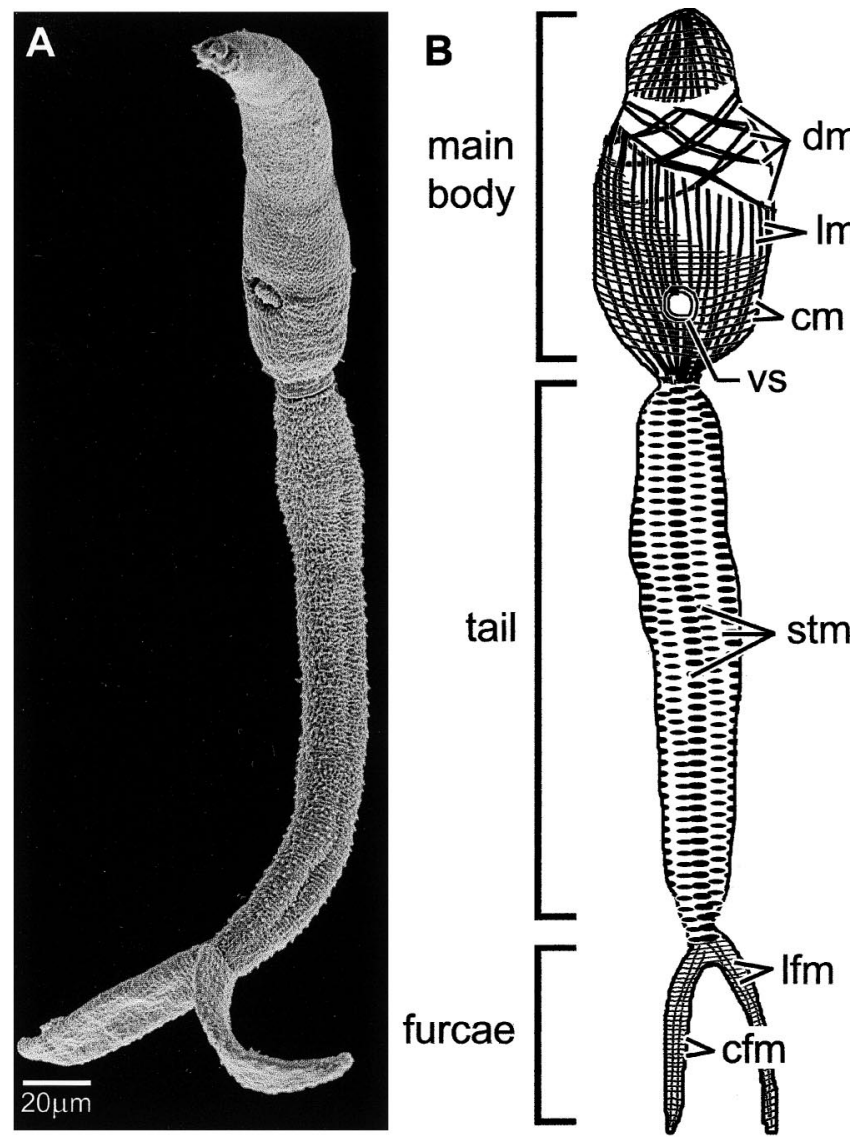

FIGURE 1. (A) Scanning electron micrograph of a Schistosoma mansoni cercaria (scale as indicated) and (B) a schematic representation of its gross muscle fiber organization. $\mathrm{Cfm}$, circular muscle fibers in the furcae; $\mathrm{cm}$, circular muscle fibers; dm; diagonal muscle fibers; lfm, longitudinal muscle fibers in the furcae; $1 \mathrm{~m}$, longitudinal muscle fibers; stm; striated tail musculature; vs, ventral sucker. 

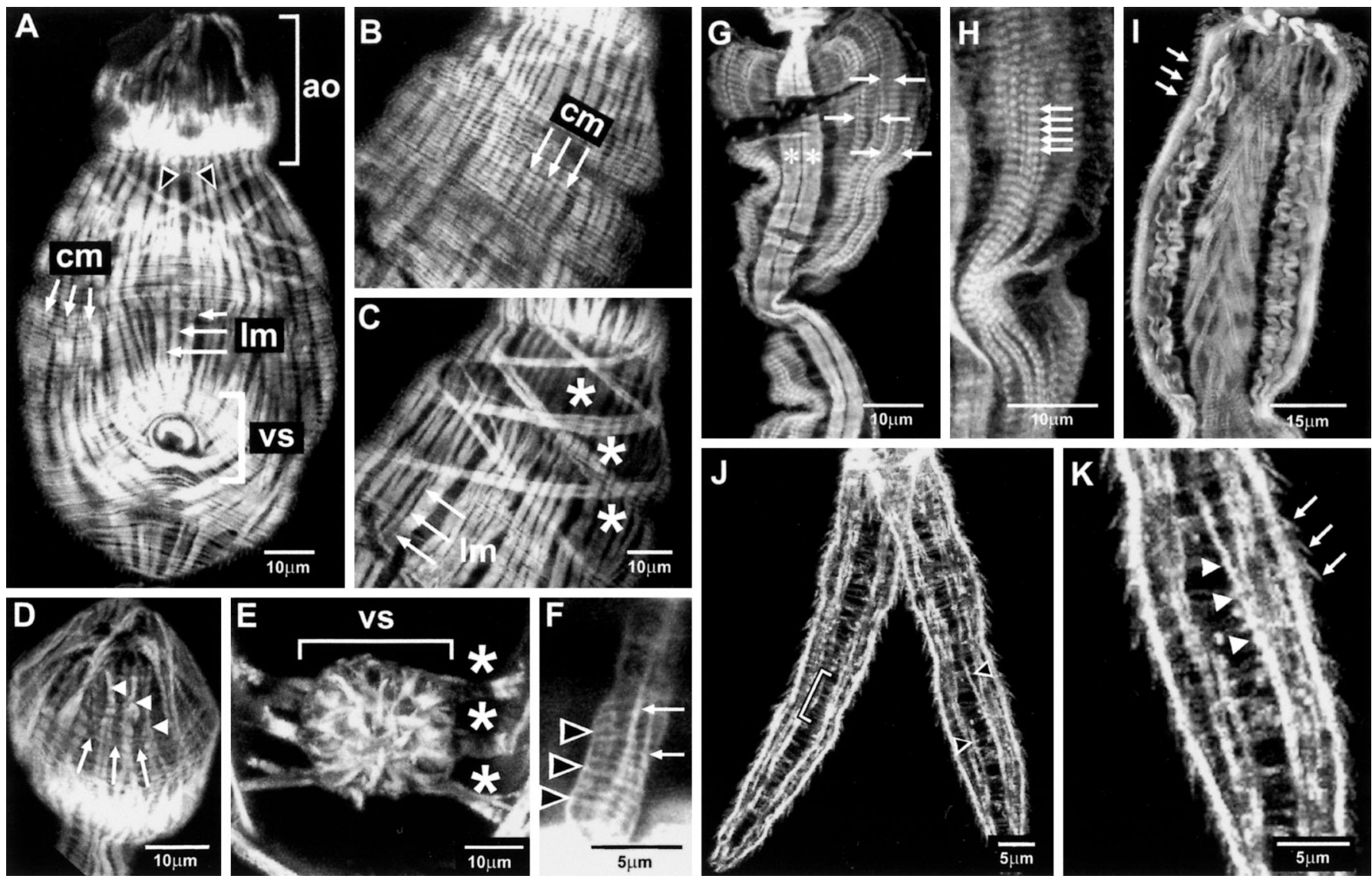

FIGURE 2. Confocal scanning laser micrographs of Schistosoma mansoni cercaria stained with phalloidin-FITC showing the different muscle fiber systems in the main body, tail, and furcae (scales as indicated). (A) General view of the ventral body wall musculature, comprising largely circular $(\mathrm{cm})$ and longitudinal $(\mathrm{lm})$ muscle fibers. ao, Anterior cone; vs, ventral sucker or acetabulum. (B-C) Sequential Z-series scan through the dorsal body wall musculature showing outermost circular muscle fibers $(\mathrm{cm})$, intermediate longitudinal muscle fibers (lm), and 3 packs of innermost diagonal muscle fibers (stars). (D) Muscle fiber arrangement in the anterior cone with longitudinal (arrowheads) and circular (arrows) muscle fibers. (E) The ventral sucker or acetabulum (vs) contains a dense array of muscle fibers and is anchored to the body wall by 3 pairs of muscle fiber packs on either side (stars). (F) Detailed view of the esophagus with circular (arrowheads) and longitudinal myofibers (arrows). (G) View of the cercarial tail with multiple, parallel-running fibers showing clear striations (arrows). (H) Detail of striations (arrows) of the cercarial tail musculature. (I) A braided arrangement of the central striated tail musculature was evident in a single specimen. The surface shows numerous surface spines (arrows). (J) Overview of the paired terminal furcae, which contain few longitudinal fibers (arrowheads) and multiple circular or transverse fibers (bracket). (K) Detail of cercarial furcae with few prominent longitudinal fibers (arrowheads) and surface spines (arrows).

muscle fiber bundles on either side (Fig. 2E). These fibers appear sometimes frayed or bifurcated. The cup of the sucker is poorly developed and shows few signs of the organization seen in adult schistosomes (Mair et al., 2000). The fine structural detail of the cercarial acetabulum has been recorded by electron microscopy (Cousin et al., 1995).

The esophagus shows an organization of circular and longitudinal muscle fibers (Fig. 2F) identical to that seen in adult worms (Mair et al., 2000). Also visible by phalloidin staining are the paired ducts of the head gland in the anterior region of the main body (not shown); however, no distinct muscle fiber is apparent in association with the ducts, and it is unclear as to what actin-containing component is responsible for the staining.

The tail stem musculature comprises an outer circular layer, resembling that of the body segment, within which are distinctive longitudinal arrays of pseudostriated muscle fibers exhibiting Z-like lines at intervals of $<1 \mu \mathrm{m}$ (Fig. 2G-I). These herringbonelike striations revealed through phalloidin-FITC staining are most likely equivalent to the ordered arrangement of tubular sarcoplasmic reticulum and associated dense bodies seen in electron micrographs of cercarial tail stem ultrastructure (Lumsden and Foor, 1968; Nuttman, 1974; Reger, 1976; Dorsey et al., 2002). In our material, individual myofibers lie in parallel on either side of the centrally located excretory duct (Fig. 2G). In 1 instance, however, these fibers appeared braided in the center of the tail
(Fig. 2I). It is unclear which of the 2 observed arrangements is 'normal.' A possible fixation artifact seems unlikely because longitudinal fibers elsewhere in this region were not at variance with those in other specimens. Their braided arrangement is reminiscent of helical muscles that play a stiffening role in the gut of gastrotrichs (Hochberg and Litvaitis, 2001). Unfortunately, examination of transmission electron micrographs of the stratified tail musculature provided little or no information on the characteristic pattern of the fibers in the tail stem. Any form of striation is rarely observed in flatworm muscle because it is predominantly of the smooth invertebrate type. Apart from cercarial tail musculature, pseudostriated muscle appears to be limited to few parasitic species with specialized adhesive structures, e.g., in the bulb musculature of the trypanorhynch cestode Grillotia erinaceus (Ward et al., 1986).

The tail furcae contain a few longitudinal fibers together with a number of transverse and circular myofibers that collectively may function in the rowinglike movement of the furcae during cercarial swimming (Fig. 2J, K). It is known that cercariae can readily switch from backward swimming to forward swimming or vice versa depending on how they align the branches of the tail (Graefe et al., 1967). Noticeable also are the numerous backward-pointing, actin-containing spines of the tegument of the tail stem and furcae (Fig. 2K). A schematic interpretation of the major anatomical features of the musculature of $S$. mansoni cercariae is depicted in Figure 1B. 
The results described show an elaborate pattern of myofiber organization within $S$. mansoni cercariae. Some of the muscles, such as the pseudostriated fibers of the tail stem, are specific to this life cycle stage; some are identical (esophagus musculature) or similar (body wall musculature) to those found in the adult worm; others have yet to develop, e.g., those of the ducts of the male and female reproductive systems. Questions raised by this investigation include the process of myogenesis during transformation of the cercaria to schistosomule and adult worm and the functional properties of the different muscle systems in cercarial motility. Analyses of the swimming motions of $S$. mansoni cercariae reveal that the numerous longitudinal muscles of the tail stem contract alternately, bending it from side to side as a rowing device, with the furcae functioning as oar blades (Graefe et al., 1967). Comparison of larval and adult schistosome muscle patterns indicates new or additional growth of muscle fibers within the entire body, such as the diagonal fibers within the body wall musculature and muscle fibers underlying the paired intestinal ceca, and generation of the muscle components of the reproductive tracts. Some of the adult musculature may develop directly from larval musculature or grow from undifferentiated stem cells present in the larvae; however, there are no reports thus far that identify the mechanism of myogenesis in the transformation of cercaria to the adult schistosome.

Clearly, as the tissues responsible for motility, body wall musculature and tail musculature play an important role in host location for the shortlived cercaria. Innervation of muscle in Schistosoma has been shown to be reactive to both classical (acetylcholine and biogenic amines) and peptide neurotransmitters/modulators (FMRFamide-related peptides and the neuropeptide Y homologue neuropeptide F) (see Halton and Gustafsson, 1996, for a review). An involvement of neuroactive substances in muscle control in Schistosoma has been demonstrated in experiments using individual muscle fibers isolated from the worm (Day et al., 1994, 1997).

This work was funded by NIH grant ROI-AI49162. We are grateful to Fred A. Lewis, Schistosomiasis Laboratory, Biomedical Research Institute, Rockville, Maryland, for supplying the infected B. glabrata snails used in this work through NIH-NIAID contract NO1-AI-55270 and to Gerard P. Brennan, Queen's University Belfast, for assistance with the scanning electron microscopy.

\section{LITERATURE CITED}

Cohen, L. M., H. Neimark, And L. K. Eveland. 1980. Schistosoma mansoni: Response of cercariae to a thermal gradient. Journal of Parasitology 66: 362-364.

Combes, C., A. Fournier, H. Mone, And A. Theron. 1994. Behaviours in trematode cercariae that enhance parasite transmission: Patterns and processes. Parasitology 109: S3-S13.

Cousin, C., C. Dorsey, V. Kennedy, And K. Ofori. 1995. Ultrastructure of the ventral sucker of Schistosoma mansoni cercaria. Journal of Morphology 223: 215-223.

Day, T. A., A. G. Maule, C. Shaw, D. W. Halton, S. Moore, J. L. BennetT, AND R. A. PAX. 1994. Platyhelminth FMRFamide-related peptides (FaRPs) contract Schistosoma mansoni (Trematoda; Digenea) muscle fibres in vitro. Parasitology 109: 445-459.

$\longrightarrow,-,-$ AND R. A. PAX. 1997. Structure-activity relationships of FMRFamide-related peptides induced contractions of Schistosoma mansoni muscle. Peptides 18: 917-921.

Dorsey, C. H., C. E. Cousin, F. A. Lewis, and M. A. Stirewalt. 2002. Ultrastructure of the Schistosoma mansoni cercaria. Micron 33: 279-323.

Fetterer, R. H., R. A. Pax, S. Strand, and J. L. Bennett. 1978. Schistosoma mansoni: Physical and chemical factors affecting the mechanical properties of the adult male musculature. Experimental Parasitology 46: 59-71.

Graefe, G., W. Hohorst, and H. Drager. 1967. Forked tail of the cercaria of Schistosoma mansoni-A rowing device. Nature 215: 207-208.

HaAs, W., D. Diekhoff, K. Koch, G. Schmalfuss, and C. Loy. 1997. Schistosoma mansoni cercariae: Stimulation of acetabular gland secretion is adapted to the chemical composition of mammalian skin. Journal of Parasitology 83: 1079-1085.

Halton, D. W., and M. K. S. Gustafsson. 1996. Functional morphology of the platyhelminth nervous system. Parasitology 113: S47S72.

Hochberg, R., AND M. Litvaitis. 2001. The muscular system of Dactylopodola baltica and other macrodasyidan gastrotrichs in a functional and phylogenetic perspective. Zoologica Scripta 30: 325336.

Hooge, M. D., AND S. Tyler. 1999. Musculature of the facultative parasite Urastoma cyprinae (Platyhelminthes). Journal of Morphology 241: 207-216.

LuMSDEN, R. D., AND W. E. FoOR. 1968. Electron microscopy of schistosome cercarial muscle. Journal of Parasitology 54: 780-794.

Mair, G. R., A. G. Maule, T. A. Day, and D. W. Halton. 2000. A confocal microscopical study of the musculature of adult Schistosoma mansoni. Parasitology 121: 163-170.

NuttMan, C. J. 1974. The fine structure and organization of the tail musculature of the cercaria of Schistosoma mansoni. Parasitology 68: $147-154$.

REGER, J. F. 1976. Studies on the fine structure of cercarial tail muscle of Schistosoma sp. (Trematoda). Journal of Ultrastructure Research 57: 77-86.

Reiter, D., B. Boyer, P. Ladurner, G. R. Mair, W. Salvenmoser, And R. M. RIEGER. 1996. Differentiation of the body wall musculature in Macrostomum hystricinum marinum and Hoploplana inquilina (Plathelminthes), as models for muscle development in lower Spiralia. Rouxs Archives of Developmental Biology 205: 410-423.

TYleR, S., AND R. M. RIEGER. 1999. Functional morphology of the acoelomate worm, Convoluta pulchra (Platyhelminthes). Zoomorphology 119: 127-141.

Ward, S. M., G. McKerr, And J. M. Allen. 1986. Structure and ultrastructure of muscle systems within Grillotia erinaceus metacestodes (Cestoda: Trypanorhyncha). Parasitology 93: 587-597.

\title{
From First to Second and Back to First Intermediate Host: The Unusual Transmission Route of Curtuteria australis (Digenea: Echinostomatidae)
}

\author{
L. H. McFarland, K. N. Mouritsen, and Robert Poulin*, Department of Zoology, University of Otago, P.O. Box 56, Dunedin, New Zealand. ${ }^{\star}$ To \\ whom correspondence should be addressed. e-mail: robert.poulin@stonebow.otago.ac.nz
}

ABSTRACT: The trematode Curtuteria australis uses the whelk Cominella glandiformis as first intermediate host and the cockle Austrovenus stutchburyi as second intermediate host before maturing in shorebirds. The whelk also happens to be an important predator of cockles on intertidal mudflats. In this study we show that whelks can act as tem- porary paratenic hosts for the trematode. A single whelk feeding on 1 cockle can ingest large numbers of metacercariae, which remain within the whelk for 1-3 days before passing out in feces. The viability of these metacercariae, assessed as the percentage capable of successfully excysting under conditions simulating those inside a bird's digestive 
tract, is lower after passage through a whelk (48\%) than before $(59 \%)$. Still, given that shorebird definitive hosts prey on whelks as well as cockles, survival inside the whelk allows $C$. australis to complete its life cycle; overall, though, whelk predation is likely to be an important sink for the trematode population. To our knowledge, this is the first report of a trematode using a snail as both first intermediate host and paratenic host, offering an alternative transmission route for the parasite as a result of the unusual trophic relationships of its hosts.

The life cycle of a typical trematode involves 3 hosts: a definitive host in which the adult worms live, a first intermediate host in which the parasite multiplies asexually to produce cercariae, and a second intermediate host in which cercariae encyst as metacercariae and awai ingestion by the definitive host. In trematode species using this basic life cycle, however, the parasites may also take alternative transmission routes. For instance, in many species, the life cycle can be abbreviated, with the parasite facultatively omitting 1 or more hosts (Poulin and Cribb, 2002). In addition, trematode life cycles may have additiona paratenic hosts, although this possibility often goes unnoticed; paratenic hosts are hosts that may play roles in transmission but in which no parasite development takes place. Intermediate hosts of trematodes may be parts of complex networks of trophic relationships, and for some species many roads may lead to the definitive host. For example, the microphallid Maritrema arenaria uses barnacles as second intermediate hosts and birds as definitive hosts. McCarthy et al. (1999) recently documented that metacercariae of $M$. arenaria survive passage through the predatory snail Nucella lapillus, which feeds on barnacles. Because the bird definitive hosts of the parasite feed on the snails as well as barnacles, the trematode can use $N$. lapillus as paratenic hosts. Alternative transmission pathways like this one may be common in natural systems, where trematodes may accommodate the various trophic relationships involving their hosts.

The trematode Curtuteria australis (Echinostomatidae) may be in such a situation. Adult $C$. australis live in the gut of oystercatchers Haematopus spp. (Allison, 1979) but also occur in gulls Larus spp. (B. L. Fredensborg, pers. comm.) and probably other shorebirds. They use the whelk Cominella glandiformis (Buccinidae) as first intermediate hosts and the common cockle Austrovenus stutchburyi (Veneridae) as second intermediate hosts, in which they encyst in the foot (Allison, 1979). Whelks are common scavengers-predators on soft-sediment intertidal areas throughout New Zealand (Morton and Miller, 1973). They are often seen feeding in groups on a cockle, leaving behind only a clean shell. Ansell (2001) estimated that 3-9\% of cockles fall prey to whelks every year. Predation of a second intermediate host by the first intermediate host is unusual among known trematode life cycles. In the Otago Harbour (South Island, New Zealand), the prevalence of C. australis metacercariae in cockles is virtually $100 \%$, and mean numbers of metacercariae per cockle exceed 100 in most localities. Thus, whelks accidentally ingest large numbers of metacercariae, representing a considerable proportion, i.e., 3-9\%, of the pool of available metacercariae Oystercatchers and other potential avian definitive hosts of $C$. australis are known to feed on whelks (Fordham, 1970; Baker, 1974). If metacercariae remain viable during their passage inside whelks, they could use these snails as paratenic hosts. This would allow the trematode to extend its chance of transmission to birds beyond the death of the cockle host. The aim of the present study was to assess the potential role of whelks as paratenic hosts for $C$. australis using feeding experiments under laboratory conditions.

Whelks and cockles were collected in June 2002 from Lower Portobello Bay, Otago Harbour, close to the low watermark, and returned live to the laboratory. Cockles were kept in a large tank filled with seawater, at room temperature (20-25 C) and under a natural photoperiod. Whelks were kept under the same conditions but placed individually in small plastic containers (4-cm diameter) half-filled with seawater.

For the feeding experiment, 40 whelks (shell height $17.0 \pm 0.2 \mathrm{~mm}$ [mean $\pm \mathrm{SE}]$ ) were starved for 3 days before each was fed the foot of 1 cockle. In each case, the cockle foot was measured (length at the base) and cut off and then pressed firmly between 2 microscope slides. Metacercariae visible on each side of the foot were counted under the microscope $(\times 10)$ before the entire intact foot was given to a whelk to feed on. These visual estimates of the number of metacercariae per cockle foot slightly but consistently underestimate the true number. In a separate sample of 15 cockles, we obtained both a visual estimate of the number of metacercariae in the foot and an actual total count obtained after digestion of the foot in a pepsin solution $(6 \mathrm{~g}$ pepsin and 7 $\mathrm{ml} \mathrm{HCl}$ in $1,000 \mathrm{ml}$ water) at $40 \mathrm{C}$ for $4 \mathrm{hr}$. This procedure allows the recovery and count of all metacercariae under the microscope, including those that were not visible because they were deeply embedded in the foot (Lepitzki et al., 1994). From these 15 cockles, we obtained a regression equation (actual number $=64.6+1.57$ (visual estimate), $r^{2}=$ $0.87, P=0.0001$ ) that allowed actual numbers of metacercariae per foot to be extrapolated for all cockle feet fed to whelks.

After $1.5 \mathrm{hr}$ of feeding on a cockle foot (most whelks had finished feeding within $1 \mathrm{hr}$ ), each whelk was transferred to a new container with fresh seawater. Cockle flesh, if any, remaining in the original containers was digested in a pepsin solution, as above, and the remaining metacercariae were counted and subtracted from the total number initially given to the whelks to obtain the number actually eaten. Four of the 40 whelks were excluded from the experiment because they either did not eat any foot tissue or did not produce feces, leaving 36 whelks in the following analyses. During the 5 days after the feeding period, fecal checks were made 4 times daily. When feces were found, they were pipetted out of the whelk's container, placed in a petri dish, and examined under the microscope. The number of metacercariae in each fecal deposit was recorded. Their viability was assessed by in vitro excystment under conditions simulating those inside a bird's digestive tract. The metacercariae were placed in petri dishes in an excystment solution consisting of $5 \mathrm{ml}$ of bicarbonate saline $(0.8 \% \mathrm{w} / \mathrm{v}$ sodium chloride and $1.5 \% \mathrm{w} / \mathrm{v}$ sodium bicarbonate) containing $0.8 \% \mathrm{w} / \mathrm{v}$ sodium taurocholate and $0.3 \% \mathrm{w} / \mathrm{v}$ trypsin, and $5 \mathrm{ml} 0.02 \mathrm{M}$ hydrochloric acid containing 0.8\% w/v L-cysteine (Irwin et al., 1984; Irwin, 1997). They were left in the solution for $1 \mathrm{hr}$ at $40 \mathrm{C}$ and then examined under the microscope $(\times 40)$. Fully excysted and moving worms were counted as viable, whereas those not fully excysted or motionless were considered as dead.

To compare these results with the viability of metacercariae that have not passed through a whelk, the foot of each of 20 cockles was measured and cut off. The number of metacercariae it contained was estimated as above. These 20 cockles did not differ in either foot length $(t$ $=0.453, P=0.652$ ) or numbers of metacercariae harbored (using logtransformed data: $t=0.257, P=0.798$ ) from those fed to whelks. The foot was then carefully fragmented in seawater using needles and placed in a weak pepsin solution ( $1 \%$ pepsin, $0.85 \% \mathrm{NaCl}, \mathrm{pH} 2)$ to remove layers of host tissue and expose the metacercariae (Irwin, 1997). These were then placed in the excystment solution and assessed for viability as those recovered from whelk feces.

A total of 4,373 (range 6-281 per snail) metacercariae of C. australis were recovered from the feces of the 36 experimental whelks. None had passed out $24 \mathrm{hr}$ after their ingestion by whelks; after $48 \mathrm{hr}$, approximately $50 \%$ of the metacercariae had come out, and by $72 \mathrm{hr}$ after ingestion, they had all been evacuated. There was a relatively strong positive correlation between the number of metacercariae eaten by a whelk and the number recovered from its feces $(r=0.689, P=0.0001)$ : the more metacercariae went in, the more came out (Fig. 1). The lack of an obvious asymptote (even with untransformed data) suggests that within the range of numbers ingested by the whelks, there is no clear upper limit on how many metacercariae can transit through a whelk.

The viability of metacercariae, i.e., the percentage that excysted, showed no density dependence. Rather, the percentage of viable metacercariae among those egested by whelks correlated positively with the number of metacercariae eaten $(r=0.413, \mathrm{n}=36, P=0.0124)$. This association likely results from the percentage of viable metacercariae being correlated positively with the total number of metacercariae in the cockles from which they originated $(r=0.401, \mathrm{n}=36, P=$ $0.0154)$. The more heavily infected cockles had perhaps been exposed to recent waves of infection, resulting in a high proportion of new viable metacercariae in their tissue. Whatever the explanation, it is clear that the viability of metacercariae in whelks is not decreased when high numbers are ingested. The viability is also not seriously affected by passage time through the whelks. A comparison of metacercariae in feces egested within $48 \mathrm{hr}$ after ingestion with those egested more than $64 \mathrm{hr}$ after ingestion indicates no significant difference in viability ( $t=$ $1.66, P=0.106)$, although lower percentages of excystment were more common in groups of metacercariae from the latter group. There was, however, an effect of ingestion by and passage through a whelk on 


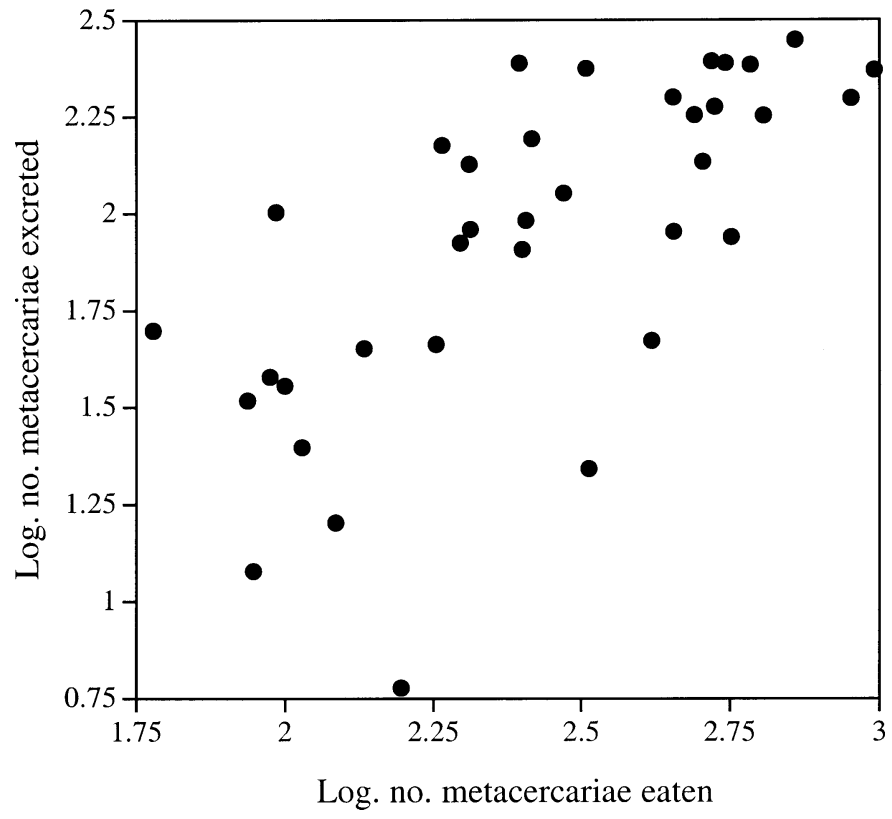

FIGURE 1. Relationship between the number of metacercariae of the trematode Curtuteria australis ingested by whelks and the number that passed out in whelk feces.

metacercarial viability (Fig. 2). The viability of metacercariae that passed through whelks was on average 19\% lower than that of metacercariae taken straight out of cockles (using arcsine-transformed data: $t=2.159, P=0.0353$ ).

Our results show that metacercariae of the trematode $C$. australis can survive passage through a whelk when the latter preys on cockles. Metacercariae can stay up to 3 days in whelks, and about half of them are viable and can develop into adults should a bird definitive host feed on the whelk. To our knowledge, this is the first report of a snail first intermediate host also being used as a paratenic host by a trematode, thus accommodating the unusual trophic relationship between its hosts.

Almost $60 \%$ of metacercariae taken straight from cockles and placed in the cysteine solution excysted successfully. Clearly, dead metacercariae remain in cockle tissues for some time. The significantly lower excystment rate observed in metacercariae that passed through a whelk suggests that there is an additional mortality factor associated with this passage. The most likely cause is the possible physical damage that some metacercariae may incur as whelks feed on cockle tissue. Although the metacercariae are small (200-250 $\mu \mathrm{m}$ in diameter), their cyst risks being punctured by the whelk's radula during feeding. Still, the survivorship of the trematode in its temporary paratenic whelk host is high enough to provide an extended transmission period after the death of the second intermediate host.

The trematode may indirectly facilitate predation of whelks on cockles and thus inadvertently increase its likelihood of passing through a whelk. Metacercariae of C. australis are found encysted in the foot of cockles, directly impairing the burrowing ability of their cockle host and leaving them stranded at the surface of the sediments (Thomas and Poulin, 1998; Mouritsen, 2002). This results in increased bird predation on cockles and therefore increased parasite transmission to the definitive host (Thomas and Poulin, 1998), but it should also make it easier for whelks to find and prey on cockles. If these also happen to be the most heavily infected, much more than 3-9\% (based on Ansell, 2001) of $C$. australis metacercariae may pass through whelks. This alternative transmission route may therefore be taken by a large proportion of metacercariae. However, given their short residence time in whelks, many of them will be lost from the system; although a few metacercariae reach birds after ingestion by a whelk, in general, whelk predation represents an important sink for the trematode population.

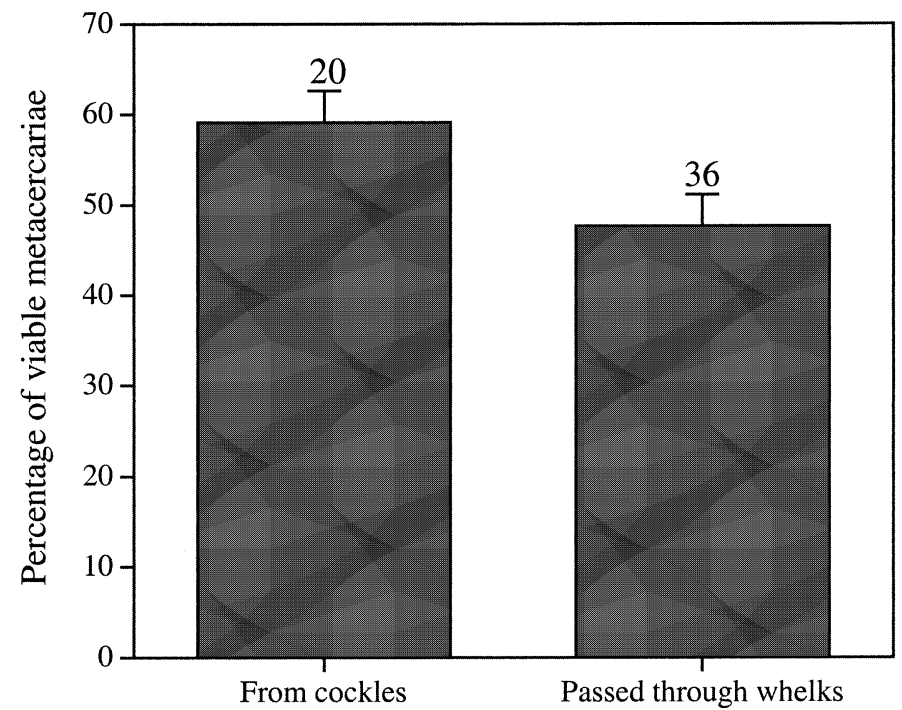

Origin of metacercariae

FIGURE 2. Mean \pm SE viability (percentage of worms that excysted successfully) of metacercariae of the trematode Curtuteria australis taken directly from its cockle second intermediate host or after passage through whelks. Numbers of cockles or whelks from which the metacercariae were obtained are indicated above each column.

Whelks are unlikely to serve as temporary paratenic hosts for another trematode parasitic in cockles, which matures in avian hosts just as $C$. australis. An unidentified gymnophallid occurs in cockles in the Otago area, although at a lower prevalence and in fewer localities than $C$. australis; its metacercariae are found in host epithelium near the hinge of the shell (Poulin et al., 2000). They could not survive inside a whelk after predation on cockle hosts, however, because they are not encysted. Still, the results presented in this study demonstrate that parasite transmission can follow routes other than the classical life cycles presented in textbooks and that transmission must be considered within the framework of the trophic interactions in which it operates in nature.

We thank J. Duthie and K. Hedley for technical assistance and S. W. B. Irwin for advice. This research was partially supported by a grant from the Marsden Fund, and K.N.M. was supported by the Danish Natural Science Research Council.

\section{LITERATURE CITED}

Allison, F. R. 1979. Life cycle of Curtuteria australis n. sp. (Digenea: Echinostomatidae: Himasthlinae), intestinal parasite of the South Island pied oystercatcher. New Zealand Journal of Zoology 6: 1320.

ANSELL, A. D. 2001. Dynamics of aggregations of a gastropod predator/ scavenger on a New Zealand harbour beach. Journal of Molluscan Studies 67: 329-341.

BAKER, A. J. 1974. Prey specific feeding methods of New Zealand oystercatchers. Notornis 21: 219-233.

FoRDHAM, R. A. 1970. Mortality and population change of dominican gulls in Wellington, New Zealand. Journal of Animal Ecology 39: $13-27$.

IRwIN, S. W. B. 1997. Excystation and cultivation of trematodes. In Advances in trematode biology, B. Fried and T. K. Graczyk (eds.). CRC Press, Boca Raton, Florida, p. 57-86.

-, G. McKerr, B. C. Judge, And I. Moran. 1984. Studies on metacercarial excystment in Himasthla leptosoma (Trematoda: Echinostomatidae) and newly emerged metacercariae. International Journal for Parasitology 14: 415-421.

Lepitzki, D. A. W., M. E. ScotT, And J. D. McLaughlin. 1994. Influence of storage and examination methods on the recovery and size of metacercariae of Cyathocotyle bushiensis and Sphaeridotrema pseudoglobulus (Digenea). Journal of Parasitology 80: 454-460.

McCarthy, H. O., S. W. B. Irwin, and S. M. FitZPatRick. 1999. Nu- 
cella lapillus as a paratenic host for Maritrema arenaria. Journal of Helminthology 73: 281-282.

Morton, J., AND M. Miller. 1973. The New Zealand sea shore, 2nd ed. Collins, London, U.K., 653 p.

Mouritsen, K. N. 2002. The parasite-induced surfacing behaviour in the cockle Austrovenus stutchburyi: A test of an alternative hypothesis and identification of potential mechanisms. Parasitology 124: $521-528$.
Poulin, R., And T. H. CRibi. 2002. Trematode life cycles: Short is sweet? Trends in Parasitology 18: 176-183.

-, M. J. Steeper, AND A. A. Miller. 2000. Non-random patterns of host use by different parasite species exploiting a cockle population. Parasitology 121: 289-295.

Thomas, F., AND R. Poulin. 1998. Manipulation of a mollusc by a trophically transmitted parasite: Convergent evolution or phylogenetic inheritance? Parasitology 116: 431-436.

J. Parasitol., 89(3), 2003, pp. 628-630

(C) American Society of Parasitologists 2003

\title{
Protracted Shedding of Oocysts of Neospora caninum by a Naturally Infected Foxhound
}

\author{
J. W. McGarry, C. M. Stockton, D. J. L. Williams, and A. J. Trees, Veterinary Parasitology Group, Liverpool School of Tropical Medicine and
} Faculty of Veterinary Science, University of Liverpool, Pembroke Place, Liverpool L3 5QA, U.K. e-mail: j.w.mcgarry@liverpool.ac.uk

ABSTRACT: Feces from 15 dogs at 2 different foxhound kennels in the U.K. were examined microscopically for the presence of oocysts of Neospora caninum. One sample containing approximately 400 candidate oocysts per gram was positive in a polymerase chain reaction (PCR) using $N$. caninum-specific primers. In a sample taken 4 mo later from the same hound, $N$. caninum oocysts were again detected visually and by PCR. This is the third reported case of a dog naturally excreting oocysts of $N$. caninum and suggests that oocyst excretion can occur over a relatively long period of time in some circumstances or that reshedding may occur.

Neospora caninum is the most frequently diagnosed cause of abortion in cattle throughout the world (Dubey, 1999). The major route of transmission in cattle is transplacental (Dubey and Lindsay, 1996), but there is circumstantial evidence that epidemic $N$. caninum-associated abortions in cattle are caused by external sources of infection (Yaeger et al., 1994; McAllister et al., 1996; Dijkstra, Barkema et al., 2001). Dogs have been shown to be definitive hosts of $N$. caninum, shedding oocysts after experimental infection (McAllister et al., 1998; Lindsay et al., 1999). Point sources of infection are likely to be caused by oocyst contamination of pasture or feed. Infections in cattle herds have been linked to infections in dogs (Wouda et al., 1999). An association between abortion risk or the occurrence of postnatal infection and abortion and the presence of dogs has been found (Parè et al., 1998; Bartels et al., 1999; Djikstra et al., 2002). Calves and cows have been infected experimentally by oocysts (De Marez et al., 1999; Trees et al., 2002), but low doses of oocysts do not cause abortion in cows.

The number of oocysts and the dynamics of their excretion into the environment profoundly influence the epidemiology of coccidian diseases such as ovine toxoplasmosis. In the acute phase of infection, cats may shed several million oocysts of Toxoplasma gondii in 1-2 wk (Dubey and Frenkel, 1972; Dubey, 1976). In some flocks in the U.K., 70-90\% of sheep are seropositive for T. gondii (Watson and Beverley, 1971). Approximately 1,500 T. gondii oocysts or fewer provoke abortion in sheep (Owen et al., 1998), but the minimal pathogenic dose is unclear. Dogs fed tissue containing $N$. caninum cysts shed low numbers of oocysts inconsistently for up to 19 days (McAllister et al., 1998; Lindsay et al., 1999; Dijkstra, Eysker et al., 2001). The detection of oocysts of $N$. caninum has been reported from 2 naturally infected dogs. In 1 case, the number of oocysts excreted was undetermined but was thought to be low (Basso et al., 2001), and in the other a total of 1 million oocysts were recovered using a sugar concentration method (Šlapeta et al., 2002). The pattern of excretion or quantity of feces examined was not reported.

In the U.K., foxhounds are routinely fed bovine carcasses and have a higher prevalence of $N$. caninum antibodies than do pet dogs (Trees and Williams, 2000). We, therefore, investigated their role as definitive hosts. Polymerase chain reaction (PCR) was used to confirm the identity of oocysts because the investigation of definitive hosts for N.caninum has been complicated by the presence of oocysts of other apicomplexan parasites, e.g., Hammondia spp. (Schares et al., 2002). Here, we report the case of a 6-yr-old British foxhound that had shed low numbers of oocysts when examined on 2 occasions almost 4 mo apart. The epidemiological significance of these observations is discussed.

During the period April-June 1999, 15 fresh fecal samples were obtained from 2 different foxhound kennels in the north of U.K. All hounds were bred on site but were fostered in domestic homes before returning to the packs at approximately $18 \mathrm{mo}$ of age. Ages varied from 18 mo to 8 yr. Samples were taken from the pens of individual animals isolated the night before. One male dog in which putative $N$. caninum oocysts were detected was sampled on 3 occasions: 16 June 1999, 15 October 1999, and 4 November 1999.

Fecal samples were screened by microscopy after centrifugal flotation in saturated sodium chloride using a semiquantitative coverslip method. Briefly, $1 \mathrm{~g}$ of feces was homogenized by vortexing in $15 \mathrm{ml}$ of saturated $\mathrm{NaCl}$ with glass beads. A coverslip was placed immediately on top of the tube, and the tube was centrifuged at $700 \mathrm{~g}$ for $2 \mathrm{~min}$ and quickly lifted off. Protozoan cysts were counted. For PCR, $10 \mathrm{~g}$ of feces was homogenized in $50 \mathrm{ml}$ of distilled water and washed 3 times after straining through a $100-\mu \mathrm{m}$-mesh sieve. The final sediment was mixed with saturated $\mathrm{NaCl}$ and centrifuged as above. The surface layer of the supernatant that contained oocysts was washed 3 times in water and resuspended in $100 \mu \mathrm{l}$ of Tris-ethylenediaminetetraacetic acid buffer, $\mathrm{pH}$ 8.0. DNA was prepared from the suspension using a DNeasy ${ }^{\mathrm{R}}$ kit according to the manufacturer's instructions for DNA extraction from tissues (Qiagen, Crawley, Sussex, U.K.).

To confirm that the DNA extraction procedure was effective using oocysts, experimentally produced $N$. caninum oocysts (obtained from M. M. McAllister, Department of Veterinary Pathobiology, VMBSB, Urbana, Illinois) were diluted in water and processed using the Dneasy $\mathrm{R}^{\mathrm{R}}$ kit (Qiagen). Neospora caninum DNA could be detected in water suspensions nominally containing a single oocyst per milliliter by PCR using the primers of Uggla et al. (1998) and Ellis et al. (1999).

DNA extracted from hound fecal samples in which oocysts had been detected by microscopy was used in PCRs using different $N$. caninum primer sets (Muller et al., 1996; Uggla et al., 1998; Ellis et al., 1999) for $N$. caninum. Two sets of $H$. heydorni-specific primers, forward primer 5'-ACGGATTCGGCGATTGAAG-3' and reverse primer $5^{\prime}$ CATCGCGTCTTCTGATTC-3', and forward primer 5' -TGAATCCCAAGCAAAACA-3' and reverse primer 5' -CTGGCATCGCATAGAGAA-3'), designed from the ITS1 region of $H$. heydorni (Ellis, Morrison et al., 1999) were tested with the sample that was PCR positive for $N$. caninum. All PCR methods were modified for use with Hot Star TAQ polymerase with recommended buffer conditions (Qiagen). Controls included in each PCR were N. caninum (Liverpool, U.K.) tachyzoite DNA or $H$. heydorni DNA used alone or spiked into DNA extracted from oocyst-negative fecal samples.

Of the 10 fecal samples taken from kennel 1 ( 80 foxhounds in the pack), 1 sample contained 378 putative $N$. caninum oocyts per gram, estimated using the semiquantitative coverslip method described earlier. Three samples contained oocysts of Sarcocystis spp. Of the 5 fecal samples examined from kennel 2 (60 foxhounds in the pack), 1 sample 
contained an estimated 84 putative $N$. caninum oocysts per gram. Four samples contained oocysts of Sarcocystis spp. Putative N. caninum oocysts from kennel 1 had a spherical to subspherical structure and measured $11.6 \pm 1 \mu \mathrm{m}$ by $11.2 \pm 0.5 \mu \mathrm{m}$, range $10.4-12.9 \mu \mathrm{m}$ by $10.6-$ $11.8 \mu \mathrm{m}(\mathrm{n}=4)$. Deoxyribonucleic acid from this sample was positive in PCRs using the primers of Muller et al. (1996), Uggla et al. (1998), and Ellis et al. (1999), giving amplification products of 337, 246, and $146 \mathrm{bp}$, respectively. The PCR of Muller et al. (1996) uses $N$. caninumspecific primers (see later). No amplicon was produced using the latter primers with $H$. heydorni DNA. Hammondia heydorni-specific primer region failed to amplify from the hound sample but gave amplicons of expected size with $H$. heydorni DNA.

A second sample was taken from the same hound 4 mo later, and the presence of $N$. caninum-like oocysts was again confirmed by microscopic examination. Oocysts in this sample were not measured or quantified because limited material was available and oocysts were very scarce. The sample was positive by PCR using primers specific for $N$. caninum (Muller et al., 1996; Uggla et al., 1998; Ellis et al., 1999). Neospora caninum oocysts were not detected visually or by PCR in a third sample taken from the dog 5 mo after the original sample was acquired.

The sample that contained an estimated 84 oocysts per gram (from kennel 2) was negative by PCR using the 3 sets of $N$. caninum primers described above. These oocysts had a similar morphological appearance and size as those seen in the first hound sample. The identity of these oocysts was not investigated further.

This is the third report identifying $N$. caninum oocysts in a naturally infected dog. The identity of oocysts was confirmed as $N$. caninum by PCR using primer sets of Muller et al. (1996), which are $N$. caninum specific and do not amplify DNA from $N$. hughesi, H. heydorni, or Hammondia sp. FOX-2000/1 and Hammondia sp. FOX-2000/2 (Basso et al., 2001; Hill et al., 2001; Muller et al., 2001; Schares et al., 2002). The low numbers of oocysts detected is consistent with the numbers reported for other experimental and natural infections in dogs (McAllister et al., 1998; Lindsay et al., 1999; Basso et al., 2001; Dijkstra, Eysker et al., 2001).

There is limited information about the pattern of $N$. caninum oocyst production by dogs. McAllister et al. (1998) showed that the earliest time that oocysts were produced was 8 days after ingestion of infected tissue and that they were excreted for 7-19 days. In similar work, Lindsay et al. (1999) showed that oocysts were produced between days 6 and 9 after infection. Patterns of $N$. caninum oocyst excretion over a period of several months have not been fully investigated after primary infections in experimental dogs. Of particular interest in the present study is that oocysts were identified in the same hound some 4 mo after the first detection. Oocysts of other types of related coccidia seem to be excreted for shorter periods than this, without further reshedding. For example, cats excrete $T$. gondii oocysts for 1-2 wk after a primary infection and are thought not to excrete again, although Dubey (1976) demonstrated that reactivation of latent $T$. gondii infections with reshedding of oocysts occurs if experimental cats are subsequently infected with another common feline coccidian Isospora felis.

The possibility that the hound had become reinfected with $N$. caninum between the first and second sampling periods cannot be excluded, although Schares et al. (2001) have shown that a dog that had shed oocysts previously failed to excrete when fed infected tissues on a second occasion. Following similar observations, Dijkstra, Eysker et al. (2001) have suggested that after shedding oocysts after a primary infection, dogs may develop a gut immunity that prevents repeated shedding. The effect of dog age, breed, sex, and immune status and interactions with other apicomplexan parasites on $N$. caninum oocyst excretion is largely unknown.

Little is known about the biology of canine apicomplexan protozoans and their relative pathogenicity. Our study also revealed the presence of oocysts that were morphologically indistinguishable from $N$. canin$u m$, but DNA from these oocysts failed to amplify using $N$. caninumspecific primers. Schares et al. (2002) recently found Hammondia sp.like oocysts in fox feces and preliminarily designated these as Hammondia sp. Fox-2000/1 and Fox-2000/2. Clearly, it is important to be able to distinguish nonpathogenic species of oocysts in canine feces from those of $N$. caninum, which cause major disease in both dogs and cattle.

Foxhound packs in Britain are fed the carcasses of livestock that have died or are otherwise unfit for human consumption. Because there is a legal requirement for farmers to properly dispose of bovine carcasses, the hound packs provide a valuable disposal service for cattle farmers and consequently foxhounds are almost exclusively fed raw bovine carcasses. With the introduction of BSE regulations and the mandatory removal of the head and spinal cord from all dead stock, including those fed to hounds, the dogs should not have eaten central nervous system (CNS) tissue. Although it is not possible to exclude the possibility of access to other species or other tissues in this case, the N. caninuminfected hound would primarily have ingested bovine muscle and bone. Neospora caninum bradyzoites are most readily detected in CNS, but they have been reported in bovine muscle (Peters et al., 2001), and $N$. caninum oocysts have been described in the feces of experimentally infected dogs fed exclusively skeletal muscle of intermediate hosts (Schares et al., 2001). These findings are important in the epidemiology of neosporosis because the infectivity of muscle means that butchered meat represents a potential source of infection to dogs.

The present observations on natural protracted shedding of $N$. caninum oocysts could have a considerable epidemiological significance if this observation is confirmed. There is an urgent need to determine the role of dogs and other caniids in the spread of $N$. caninum and to elucidate the dynamics of oocyst output and the pathogenicity of oral oocyst challenge to pregnant cattle. As these issues are addressed, the role of oocyst contamination of pasture and feed in the etiology of bovine neosporosis abortion should become clearer.

We gratefully acknowledge the donation of $H$. heydorni DNA by $\mathrm{J}$. Ellis, University of Technology, Sydney, Australia.

\section{LITERATURE CITED}

Bartels, C. J. M., W. Wouda, AND Y. H. SchukKen. 1999. Risk factors for Neospora caninum-associated abortion storms in dairy herds in the Netherlands, 1995-1997. Theriogenology 52: 247-257.

Basso, W., L. Venturini, M. C. Venturini, D. E. Hill, O. C. H. Kwok, S. K. Shen, And J. P. Dubey. 2001. First isolation of Neospora caninum from the feces of a naturally infected dog. Journal of Parasitology 87: 612-618.

De Marez, T., S. Liddell, J. P. Dubey, M. C. Jenkins, and L. GasBARRE. 1999. Oral infection of calves with Neospora caninum oocysts from dogs: Humoral and cellular immune responses. International Journal for Parasitology 29: 1647-1657.

Dijkstra, Th., H. W. Barkema, H. Eysker, AND W. Wouda. 2001. Evidence of post-natal transmission of Neospora caninum in Dutch dairy herds. International Journal for Parasitology 31: 209-215.

, J. W. Hesselink, AND W. Wouda. 2002. Point source exposure of cattle to Neospora caninum consistent with periods of common housing and feeding and related to the introduction of a dog. Veterinary Parasitology 105: 89-98.

-, M. Eysker, G. Schares, F. J. Conraths, W. Wouda, and H. W. BARKEMA. 2001. Dogs shed Neospora caninum oocysts after ingestion of naturally infected bovine placenta but not after ingestion of colostrum spiked with Neospora caninum tachyzoites. International Journal for Parasitology 31: 747-752.

Dubey, J. P. 1976. Reshedding of Toxoplasma oocysts by chronically infected cats. Nature 262: 213-215.

1999. Recent advances in Neospora and neosporosis. Veterinary Parasitology 84: 349-367.

, AND J. K. FrenKel. 1972. Cyst-induced toxoplasmosis in cats. Journal of Protozoology 19: 155-177.

, AND D. S. LINDSAY. 1996. A review of Neospora caninum and neosporosis. Veterinary Parasitology 67: 1-59.

Ellis, J. T., D. McMillan, C. Ryce, S. Payne, R. Atkinson, and P. A. W. HARPER. 1999. Development of a single tube nested PCR for the detection of Neospora caninum DNA. International Journal for Parasitology 29: 1589-1596.

, D. A. Morrison, S. Liddell, M. C. Jenkins, O. B. Mohammed, C. Ryce, And J. P. Dubey. 1999. The genus Hammondia is paraphyletic. Parasitology 118: 357-362.

Hill, D. E., S. Liddell, M. C. Jenkins, and J. P. Dubey. 2001. Specific detection of Neospora caninum oocysts in faecal samples from experimentally infected dogs using polymerase chain reaction. Journal of Parasitology 87: 395-398.

Lindsay, D. S., J. P. Dubey, and R. B. Duncan. 1999. Confirmation 
that the dog is a definitive host for Neospora caninum. Veterinary Parasitology 82: 327-333.

McAllister, M. M., J. P. Dubey, D. S. Lindsay, W. R. Jolley, R. A. Willis, AND A. M. MCGuiRe. 1998. Dogs are definitive hosts of Neospora caninum. International Journal for Parasitology 28: 1473-1478.

- E. M. Huffman, S. K. Hietala, P. A. Conrad, M. L. AnderSON, AND M. D. SALMAN. 1996. Evidence suggesting a point exposure in an outbreak of bovine abortion due to neosporosis. Journal of Veterinary Diagnostic Investigation 8: 355-357.

Muller, N., H. Sager, A. Hemphill, H. Mehlhorn, A. O. Heydorn, AND B. GotTSTEIN. 2001. Comparative molecular investigation of Nc5-PCR amplicons from Neospora caninum NC-1 and Hammondia heydorni-Berlin-1996. Parasitology Research 87: 883-885.

- V. Zimmerman, B. Hentrich, and B. GotTstein. 1996. Diagnosis of Neospora caninum and Toxoplasma gondii infection by PCR and DNA hybridisation immunoassay. Journal of Clinical Microbiology 34(11): 2850-2852.

Owen, M. R., M. J. Clarkson, and A. J. Trees. 1998. Diagnosis of Toxoplasma abortion in ewes by polmerase chain reaction. Veterinary Record 142: 445-448.

Paré, J., G. Fecteau, M. Fortin, and G. Marsolais. 1998. Seroepidemiologic study of Neospora caninum in dairy herds. Journal of the American Veterinary Medical Association 213: 1595-1598.

Peters, M., E. Lutkefelr, A. R. Heckeroth, and G. Schares. 2001. Imunohistochemical and ultrastructural evidence for Neospora caninum tissue cysts in skeletal muscles of naturally infected dogs and cattle. International Journal for Parasitology 31: 1114-1148.

Schares, G., A. O. Heydorn, A. Cuppers, F. J. Conraths, and H
MeHLHORN. 2001. Hammondia heydorni-like oocysts shed by a naturally infected dog and Neospora caninum NC-1 cannot be distinguished. Parasitology Research 87: 808-816.

- H. Mehlhorn, L. GeUe, M. Peters, and F. J. ConRaths. 2002. In contrast to dogs, red foxes (Vulpes vulpes) did not shed Neospora caninum upon feeding of intermediate hosts tissues. Parasitology Research 88: 44-52.

Šlapeta, J. R., D. ModrÝ, I. Kyselová, R. HoŘejš, J. LuKeš, and B. KoudELA. 2002. Dog shedding oocysts of Neospora caninum: PCR diagnosis and molecular phylogenetic approach. Veterinary Parasitology 109: 157-167.

Trees, A. J., M. M. McAllister, C. S. Guy, J. W. McGarry, R. F. Smith, AND D. J. L. Williams. 2002. Neospora caninum: Oocyst challenge of pregnant cows. Veterinary Parasitology 109: 147-154. , AND D. J. L. Williams. 2000. Neosporosis in the United Kingdom. International Journal for Parasitology 30: 877-924.

Uggla, A., S. Stenlund, O. J. M. Holmdahl, E.-B. Jakubek, P. Thebo, H. Kindahl, AND C. BJoRKMAN. 1998. Oral Neospora caninum inoculation of neonatal calves. International Journal for Parasitology 28: $1467-1472$.

Watson, W. A., AND J. K. A. Beverley. 1971. Epizootics of toxoplasmosis causing ovine abortion. The Veterinary Record 88: 120-125.

Wouda, W., T. Dijkstra, A. M. H. Keramer, C. Van MaAnen, and J. M. A. BRINKHOF. 1999. Seroepidemiological evidence for a relationship between Neospora caninum infections in dogs and cattle. International Journal for Parasitology 29: 1677-1682.

Yaeger, M. J., S. Shawd-Wessels, and P. Leslie-SteEn. 1994. Abortion storm in a midwestern dairy. Journal of Veterinary Diagnostic Investigation 6: 506-508.

\title{
CD8+ T Lymphocytes Required for Enhanced Survival of Trypanosoma cruzi-Infected Mice at Elevated Environmental Temperature
}

\author{
Zhijun Ming and Cheryl D. Davis*†, Department of Pharmacy, School of Medicine, Soochow University, Sozhou 215007, People's Republic of \\ China. *Department of Biology, 1 Big Red Way, Western Kentucky University, Bowling Green, Kentucky 42101; †To whom correspondence \\ should be addressed.e-mail: cheryl.davis@wku.edu
}

ABSTRACT: $\mathrm{C} 3 \mathrm{H}$ mice, which are highly susceptible to infection with the Brazil strain of Trypanosoma cruzi, not only survive infection when maintained at elevated environmental temperature, but also experience reduced parasitemias, reduced tissue pathology, and enhanced immune responsiveness. The contribution of $\mathrm{CD} 8+\mathrm{T}$ cells to this phenomenon was investigated using the in vivo cell-depletion technique. The depletion of CD8 $+\mathrm{T}$ lymphocytes with purified monoclonal antibody resulted in an abrogation of the protective effects of elevated environmental temperature during $T$. cruzi infection, as evidenced by high parasitemia levels and $100 \%$ mortality in monoclonal antibody-treated mice.

Reports that elevated ambient temperature can positively influence the resistance of the vertebrate host to infection with the protozoan parasite Trypanosoma cruzi have been in the literature for over $50 \mathrm{yr}$ (Kolodny, 1939, 1940; Amrein, 1967; Marinkelle and Rodriguez, 1968). However, this phenomenon has been particularly well documented for $\mathrm{C} 3 \mathrm{H}$ mice infected with a Brazil strain of T. cruzi (Anderson and Kuhn, 1989; Dimock et al., 1991; Arif et al., 1999). Maintenance of T. cruziinfected $\mathrm{C} 3 \mathrm{H}$ mice at $36 \mathrm{C}$ not only increases longevity and decreases parasitemia, but also results in greatly reduced cardiac and skeletal muscle pathology (Arif et al., 1999).

Several investigators have suggested that the beneficial effects of elevated temperature during parasitic infection are largely attributable to enhanced humoral, or cell-mediated, immune responses. Immunosuppressive drugs such as cyclophosphamide (Otieno, 1973; Dimock et al., 1991) or whole-body X-irradiation (Otieno, 1973) have been shown to reverse the beneficial effects of elevated temperature. Furthermore, Anderson and Kuhn (1989) demonstrated that maintenance of infected mice at $36 \mathrm{C}$ results in a significant enhancement of the $T$. cruzi-specific $\mathrm{T}$ helper cell response and the direct plaque-forming cell response to sheep red blood cells. The development of humoral immunity during T. cruzi infection in $\mathrm{C} 3 \mathrm{HeB} / \mathrm{FeJ}$ mice held at $36 \mathrm{C}$ and room temperature (RT) also has been examined using a parasite-specific enzymelinked immunosorbent assay and immunoblot analysis. Although levels of anti-T. cruzi antibodies were initially lower in mice maintained at $36 \mathrm{C}$, reactivity of parasite-specific antibodies (as well as the number of parasite antigens recognized) continued to increase throughout the course of infection, peaking during the chronic stages of the disease (Dimock et al., 1991, 1992). The authors suggest that parasite-specific antibody levels peak too late to play an important role in the acute phase of infection, but it is speculated that antibodies may exert a protective effect later in infection.

Powell (1998) demonstrated that the enhanced protection observed at elevated temperature could be imparted to naive mice by the adoptive transfer of whole spleen cells from mice that have survived infection at $36 \mathrm{C}$. The adoptive transfer of spleen cells to naive, lethally infected recipients maintained at RT imparted immunity that allowed for very low parasitemias, quick clearing of trypomastigotes from the bloodstream, and a $100 \%$ survival rate. In contrast, no protection was observed in mice receiving a passive transfer of sera from mice that had survived infection at $36 \mathrm{C}$. These results strongly suggest that cellular immune responses play a significant role in controlling infection in mice maintained at elevated environmental temperature. However, the rela- 


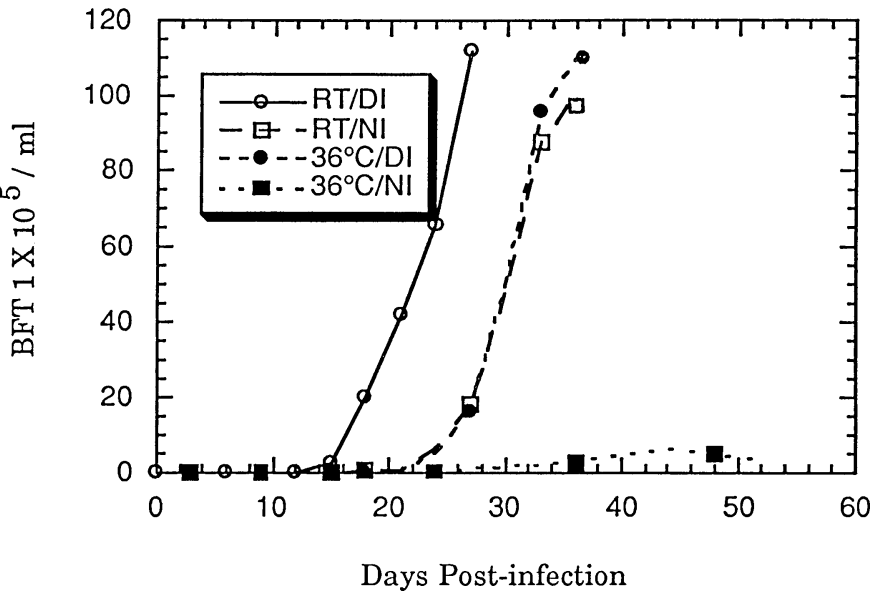

FIGURE 1. Effect of anti-CD8 or normal IgG treatment on parasitemia levels in Trypanosoma cruzi-infected mice maintained at either RT or $36 \mathrm{C}$. $\mathrm{C} 3 \mathrm{HeB} / \mathrm{FeJ}$ mice were injected with $200 \mu \mathrm{g}$ anti-CD8 monoclonal antibody or $200 \mu \mathrm{g}$ normal rat IgG for 3 consecutive days. On day 5, mice were infected with $10^{3}$ BFTs of the Brazil strain of $T$. cruzi and were immediately placed at either RT or $36 \mathrm{C}$. Antibody treatments were continued throughout the course of infection. Data are shown as mean number of BFTs per milliliter of blood (5 mice per group). (RT, room temperature; DI, depleted infected mice; NI, normal IgG-treated mice; BFT, blood-form trypomastigote.)

tive role of phenotypically different spleen cell subpopulations in this enhanced resistance to $T$. cruzi at elevated temperature has not been examined.

In the present study, in vivo cell depletion by monoclonal antibody treatment was used to study the contribution of cells bearing the CD8 glycoprotein to the observed enhanced resistance to $T$. cruzi infection in mice held at elevated environmental temperature. Female $\mathrm{C} 3 \mathrm{HeB} /$ FeJ mice (Jackson Laboratory, Bar Harbor, Maine), 8-10 wk old at the time of infection, were used in the study. All mice were maintained at RT for 2 wk before use. After antibody treatment and infection, mice were either housed at RT or placed in an environmental chamber at a temperature of $36 \mathrm{C}$. Age-matched groups of noninfected mice also were treated with antibodies and were housed at either RT or $36 \mathrm{C}$ for the entire course of the study. Food and water were provided ad libitum.

The parasites used in this study were of a Brazil strain of $T$. cruzi. These parasites were maintained in the laboratory as stock infections in $\mathrm{C} 3 \mathrm{HeB} / \mathrm{FeJ}$ mice. Mice were infected i.p. with $10^{3}$ blood-form trypomastigotes (BFTs) in $0.2 \mathrm{ml}$ of sterile Dulbecco's phosphate-buffered saline (DPBS).

Rat hybridoma 53-6.72 cells were adapted to serum-free conditions (Tarleton and Beyer, 1991) and maintained in Serum-Free and ProteinFree Hybridoma Medium (Sigma Chemical Company, St. Louis, Missouri) supplemented with penicillin $\mathrm{G}(100 \mathrm{U} / \mathrm{ml})$ and streptomycin $(100 \mu \mathrm{g} / \mathrm{ml})$. The rat hybridoma 53-6.72 secretes an IgG2a monoclonal antibody specific for murine CD8 (both the Lyt2.1 and Lyt2.2 alleles). Cells were grown in $75-\mathrm{cm}^{2}$ flasks and maintained at $37 \mathrm{C}$ with $5 \%$ $\mathrm{CO}_{2}$ and high relative humidity. The 53-6.72 monoclonal antibody was purified from culture supernatants by ammonium sulfate precipitation followed by dialysis against DPBS for $48 \mathrm{hr}$ at $4 \mathrm{C}$. The protein content of the purified monoclonal antibody was determined by Bradford assay (Bradford, 1976) and standardized to a working concentration of $1 \mathrm{mg} /$ $\mathrm{ml}$. In vivo depletion of CD8 $+\mathrm{T}$ cells was performed according to the following technique, which was adapted from the method of Kruisbeek (1991). Anti-CD8 monoclonal antibody $(200 \mu \mathrm{g})$ was injected i.p. into individual mice for 3 consecutive days. Control mice were injected with an equivalent concentration of normal rat IgG. On day 5, spleen cells from 1 mouse from each experimental group were analyzed by indirect immunofluorescence, followed by direct cell counting on an Olympus $\mathrm{BH}-2-\mathrm{RF} 1$ fluorescence microscope, to determine if satisfactory depletion had been achieved. A comparison of the percentage of CD8+ T cells present in the spleens of mice injected with 53-6.73 rat monoclonal antibody with the percentage present in mice injected with normal rat

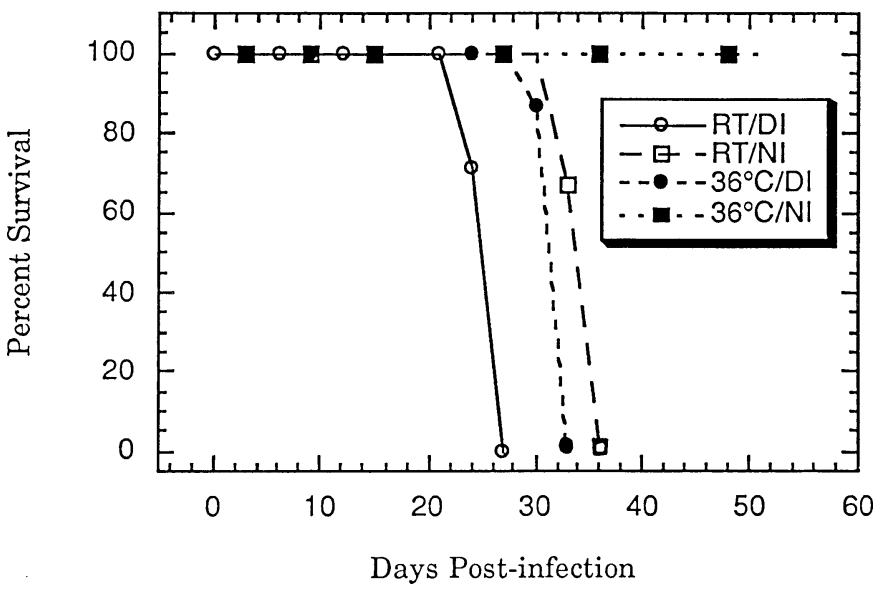

FIGURE 2. Effect of anti-CD8 or normal rat IgG treatment on survival of Trypanosoma cruzi-infected mice maintained at either room temperature or $36 \mathrm{C}$. $\mathrm{C} 3 \mathrm{HeB} / \mathrm{FeJ}$ mice were injected with $200 \mu \mathrm{g}$ antiCD8 monoclonal or $200 \mu \mathrm{g}$ normal rat IgG for 3 consecutive days. On day 5 , mice (5 per group) were infected with $10^{3}$ BFTs of the Brazil strain of $T$. cruzi and were immediately placed at either room temperature or $36 \mathrm{C}$. Antibody treatments were continued throughout the course of infection, and mortality was monitored daily. (RT, room temperature; DI, depleted infected mice; NI, normal IgG-treated mice; BFT, blood-form trypomastigote.)

IgG indicated that $>95 \%$ depletion was achieved (data not shown). Mice (the 5 remaining in each group) were then infected i.p. with $10^{3}$ BFTs and were immediately held at either RT or $36 \mathrm{C}$ as described above. To maintain the depleted condition, mice were given $200 \mu \mathrm{g}$ of 53-6.72 monoclonal antibody at 6-day intervals throughout the course of the infection. Groups of noninfected mice injected with the 53-6.72 monoclonal antibody or normal rat $\mathrm{IgG}$ according to the schedule described above also were maintained at RT or $36 \mathrm{C}$ and were monitored for control purposes. The effect of CD8 $+\mathrm{T}$ cell depletion on the course of $T$. cruzi infection in mice maintained at RT or elevated environmental temperature was determined by monitoring both parasitemia levels and longevity. Parasitemias were determined for all infected mice, beginning on day 12 of infection and continuing every 3 days throughout the course of the infection. A sample of blood was taken from the tail of each mouse and diluted in DPBS. Parasites were then counted on a hemacytometer. In addition, mice were monitored on a daily basis to determine levels of morbidity and mortality.

Mice depleted of CD8 $+\mathrm{T}$ cells showed higher parasitemia levels than did normal rat IgG-treated infected mice at both RT and $36 \mathrm{C}$ (Fig. 1). Trypomastigotes were first visible on day 13 of infection in CD8-depleted mice maintained at RT. In normal rat IgG-treated mice held at RT and in CD8-depleted mice maintained at $36 \mathrm{C}$, parasites were first seen on day 20 of infection. Parasites were not visible in the blood of normal rat IgG-treated mice maintained at $36 \mathrm{C}$ until day 29 of infection. Mean peak parasitemia levels were similar in CD8-depleted mice maintained at RT, CD8-depleted mice maintained at $36 \mathrm{C}$, and normal rat IgG-treated mice maintained at RT $\left(1.12 \times 10^{7}\right.$ parasites/ $\mathrm{ml}, 1.10 \times 10^{7}$ parasites $/ \mathrm{ml}$, and $1.0 \times 10^{7}$ parasites $/ \mathrm{ml}$, respectively). In contrast, the mean peak parasitemia for normal rat IgG-treated mice maintained at $36 \mathrm{C}$ was only $3.10 \times 10^{5}$ parasites $/ \mathrm{ml}$.

All CD8-depleted mice maintained at RT died between days 26 and 28 of infection, with a mean survival time of 27 days postinfection (Fig. 2). Normal IgG-treated mice maintained at RT died between days 32 and 36 of infection, with a mean survival time of 35 days postinfection. All CD8-depleted mice maintained at $36 \mathrm{C}$ died between days 34 and 36 of infection, with a mean survival time of 35 days postinfection. However, mice injected with normal $\mathrm{IgG}$ and held at $36 \mathrm{C}$ exhibited $100 \%$ survival through the entire course of the experiment.

The results of this study clearly demonstrate that CD8 $+\mathrm{T}$ cells are required for the enhanced survival of $T$. cruzi-infected mice maintained at elevated environmental temperature. The in vivo depletion of CD8+ $\mathrm{T}$ cells resulted in $100 \%$ mortality and advanced the onset of parasit- 
emia by approximately 9 days in mice maintained at $36 \mathrm{C}$. In addition, parasitemia levels in CD8-depleted mice held at $36 \mathrm{C}$ were comparable with those of $T$. cruzi-infected mice maintained at RT. As expected, normal rat IgG-treated infected mice held at elevated environmental temperature survived infection with $T$. cruzi and experienced very low parasitemia levels. Anti-CD8-treated infected $\mathrm{C} 3 \mathrm{H}$ mice held at $36 \mathrm{C}$ did experience a delay in the appearance of parasites in the blood as compared with anti-CD8-treated mice maintained at RT. In addition, parasitemia levels were slightly lower and mice survived for a longer period of time (approximately $1 \mathrm{wk}$ longer) when they were depleted of $\mathrm{CD} 8+\mathrm{T}$ cells and maintained at elevated temperature. This result suggests that there may be at least some direct effect of elevated temperature on the parasite. However, the primary therapeutic effect of elevated temperature during $T$. cruzi infection appears to be a CD8 $+\mathrm{T}$ cell-dependent immune response.

The results of the present study also confirm an earlier report by Tarleton (1990) showing that depletion of CD8 $+\mathrm{T}$ cells with anti-CD8 monoclonal antibody results in increased susceptibility to $T$. cruzi infection in mice maintained at RT. The importance of class I major histocompatibility complex (MHC)-restricted CD8 $+\mathrm{T}$ cells in the protective immune response against $T$. cruzi in mice maintained at RT has been documented very well (Tarleton, 1990; Tarleton et al., 1992, 1996; Nickell et al., 1993; Rottenberg et al., 1993, 1995; Nickell and Sharma, 2000). Furthermore, Garg et al. (1997) and Low et al. (1998) have shown that proteins released by $T$. cruzi within infected cells can serve as a source of peptides for MHC class I presentation and for the generation of parasite-specific cytotoxic T lymphocytes.

The precise role that CD8 $+\mathrm{T}$ lymphocytes play in the increased resistance to $T$. cruzi observed in mice maintained at an elevated ambient temperature is not yet known. Of particular interest is the question of whether or not parasite-specific CD8 $+\mathrm{T}$ cell activity is actually enhanced in infected mice maintained at $36 \mathrm{C}$. Elevated temperature has been shown to have an enhancing effect on various aspects of the vertebrate immune response and, in particular, to increase $\mathrm{T}$ cell proliferation rates in vitro (Gern et al., 1991). In addition, cytotoxic T-1ymphocyte (CTL) differentiation has been shown to be strongly temperature dependent, although there is reportedly little impact of temperature on the effector function of CTLs (Hanson, 1997). Further studies will be necessary to fully evaluate the impact of elevated temperature on the parasite-specific CTL response in this murine model of experimental Chagas' disease.

This work was supported by the Department of Biology and the Office of Graduate Studies, Western Kentucky University, Bowling Green, Kentucky. Rat hybridoma 53-6.72 cells were provided by Rick Tarleton, University of Georgia, Athens, Georgia.

\section{LITERATURE CITED}

AMreIN, Y. U. 1967. Effects of environmental temperature on Trypanosoma cruzi infection in mice. Journal of Parasitology 53: 1160.

Anderson, K. J., AND R. E. KuHn. 1989. Elevated environmental temperature enhances immunity in experimental Chagas' disease. Infection and Immunity 57: 13-17.

Arif, A. A., L. GaO, C. D. Davis, and D. S. Helm. 1999. Antibody response to heat shock proteins and histopathology in mice infected with Trypanosoma cruzi and maintained at elevated temperature. Journal of Parasitology 85: 1089-1099.

BRADFORD, M. M. 1976. A rapid and sensitive method for the quantitation of microgram quantities of protein utilizing the principle of protein-dye binding. Analytical Biochemistry 72: 248-250.

Dimock, K. A., C. D. Davis, And R. E. Kuhn. 1991. Effect of elevated environmental temperature on the antibody response of mice to Trypanosoma cruzi during the acute phase of infection. Infection and Immunity 59: 4377-4382.

1992. Changes in humoral responses to Trypanosoma cruzi during the course of infection in mice held at elevated temperature. Journal of Parasitology 78: 687-696.

Garg, N., M. P. Nunes, AND R. L. Tarleton. 1997. Delivery by Try- panosoma cruzi of proteins into the MHC class I antigen processing and presentation pathway. Journal of Immunology 158: 32933302.

Gern, J. E., J. R. Jayman, L. I. Goldberg, P. A. Murphy, and H. M. LEDERMAN. 1991. Temperature is a powerful promoter of interleukin-2 transcription. Cytokine 3: 389-397.

HANSON, D. F. 1997. Fever, temperature, and the immune response. Annals of the New York Academy of Science 813: 453-464.

Kolodny, M. H. 1939. Seasonal variations in the intensity of experimental infection with Trypanosoma cruzi in young rats. American Journal of Tropical Medicine and Hygiene 29: 131-133.

1940. The effect of environmental temperature upon experimental trypanosomiasis (T. cruzi) of rats. American Journal of Tropical Medicine and Hygiene 32: 21-23.

KRUISBEeK, A. M. 1991. In vivo depletion of CD4 and CD8 specific T cells. In Current protocols in immunology, vol. 1, J. E. Coligan, A. M. Kruisbeek, D. H. Margulies, E. M. Shevach, and W. Strober (eds.). John Wiley and Sons Publishing, Hoboken, New Jersey, p. 4.11-4.21.

Low, H. P., M. A. M. Santos, B, Wizel, and R. L. Tarleton. 1998 Amastigote surface proteins of Trypanosoma cruzi are targets for CD8+ CTL. Journal of Immunology 160: 1817-1823.

MarinKelle, C. J., AND E. RodRIGUEZ. 1968. The influence of environmental temperature on the pathogenicity of Trypanosoma cruzi in mice. Experimental Parasitology 23: 260-263.

Nickell, S. P., AND D. Sharma. 2000. Trypanosoma cruzi: Roles for perforin-dependent and perforin-independent immune mechanisms in acute resistance. Experimental Parasitology 94: 207-216.

- G. A. Stryker, and C. Arevalo. 1993. Isolation from Trypanosoma cruzi-infected mice of $\mathrm{CD} 8+$, MHC-restricted cytotoxic $\mathrm{T}$ cells that lyse parasite-infected target cells. Journal of Immunology 150: 1446-1457.

Otieno, L. H. 1972. Influence of ambient temperature on the course of experimental trypanosomiasis in mice. Journal of Tropical Medicine and Parasitology 66: 15-23.

- 1973. Effects of immunosuppressive agent on the course of Trypanosoma (Trypanozoon) brucei infection in heat-stressed mice. Transactions of the Royal Society of Tropical Medicine and Hygiene 57: 856-868.

PowelL, K. 1998. Evaluation of the success of adoptive versus passive transfer of immunity against Trypanosoma cruzi. M.S. Thesis. Western Kentucky University, Bowling Green, Kentucky, 57 p.

Rottenberg, M. E., M. Bakhiet, T. Olsson, K. Sristensson, T. Mak, H. Wigzell, AND A. ORN. 1993. Differential susceptibilities of mice genomically deleted of CD4 and CD8 to infections with Trypanosoma cruzi or Trypanosoma brucei. Infection and Immunity 61: $5129-5133$

- A. Riarte, L. Sporrong, J. Altcheh, P. Petray, A. M. Ruiz, H. WigzelL, AND A. ORN. 1995. Outcome of infection with different strains of Trypanosoma cruzi in mice lacking CD4 and/or CD8. Immunology Letters 45: 53-60.

TARLETON, R. L. 1990. Depletion of CD8+ T cells increases susceptibility and reverses vaccine induced immunity in mice infected with Trypansoma cruzi. Journal of Immunology 144: 717-724.

- AND A. M. BEYER. 1991. Medium-scale production and purification of monoclonal antibodies in protein-free medium. Biotechniques 11: 590-593.

— M. J. Grusby, M. Postan, and L. H. Glimcher. 1996. Trypanosoma cruzi infection in MHC-deficient mice: Further evidence for the role of both class I and class II-restricted T cells in immune resistance and diseases. International Immunology 8: 13-22.

, B. H. Koller, A. Latour, And M. Postan. 1992. Susceptibility of beta 2 microglobulin-deficient mice to Trypanosoma cruzi infection. Nature 356: 338-340.

, J. Sun, L. Zhang, and M. Postan. 1994. Depletion of T-cell subpopulations results in exacerbation of myocarditis and parasitism in experimental Chagas' disease. Infection and Immunity 62: $1820-1829$. 